\title{
PENERAPAN ALGORITMA K-MEANS CLUSTERING PADA K-HARMONIC MEANS UNTUK SCHEDULE PREVENTIVE MAINTENANCE SERVICE
}

\author{
Muryan Awaludin \\ Universitas Dirgantara Marsekal Suryadarma \\ Email: muryanawaludin1@gmail.com
}

\begin{abstract}
Vehicle maintenance is a very important sector in terms of economy and safety, a good understanding of vehicle maintenance is very important from the owner of the vehicle it self or from the company. Maintenance for the vehicle is considered as part structure of the activity in a series of improvements, as well as a planned activity to prevent potential errors resulting in damage. Schedule preventive maintenance is one of the methods that are used for vehicle maintenance scheduling. SPM is widely used because it can determine component reliability item, so as to reduce the cost of repairs, but this method has the disadvantage that reparations are made to the unit item could potentially breakdown, as well as the application of SPM only on certain types of vehicles. To solve this problem it is proposed the one application of a method, algorithm K-Means Clustering is one of the methods to be applied in the schedule vehicle maintenance services, $K$-Means algorithm is widely used because it is easy and simple. From the models created will then be tested using Confucion Matrix to determine how the level of accuracy, and describes the results of a positive predictive accuracy results are correct, the positive predictions were wrong, negative predictions are true, and false negative predictions. From these experiments showed that the application of $K$ Means Clustering algorithms in the vehicle's maintenance schedule capable of generating predictive value and accuracy that is optimal by $70 \%$.
\end{abstract}

Keywords: Vehicle Maintenance, K-Means Clustering, Confusion Matrix

\section{PENDAHULUAN}

Pada tahun 2014, ada lebih dari seratus juta kendaraan bermotor di Indonesi (Bermotor, 2014). Untuk alasan ini, perawatan kendaraan merupakan sektor yang sangat penting dari segi ekonomi dan keselamatan (Rubio-romero, Súarez-cebador, \& Pardoferreira, 2015), pemahaman yang baik tentang perawatan kendaraan sangatlah penting dilakukan untuk mengurangi komplain, biaya yang keluar dari perusahaan, maupun dari pemilik kendaraan itu sendiri, serta bentuk dalam menjaga lingkungan. Meskipun demikian, sangatlah sedikit perhatian oleh pemilik kendaraan dalam hal perawatan kendaraan. Kegiatan perawatan kendaraan dianggap sebagai bagian dari struktur kegiatan dalam rangkaian perbaikan (Hedvall, Dubois, \& Lind,
2016), baik dalam perawatan ringan, sedang, maupun pada tingkatan perawatan yang terbilang berat.

Penjadwalan perawatan kendaraan secara berkala merupakan salah satu cara tepat untuk mengatasi masalah tersebut, tujuannya adalah untuk memelihara kemampuan sistem dan mengendalikan biaya sehingga sistem harus dirancang serta dipelihara untuk mencapai standar mutu dan kinerja yang diharapkan. Perawatan kendaraan merupakan suatu kegiatan yang terencana untuk mencegah terjadinya kesalahan potensial yang mengakibatkan kerusakan. Perhatikan bahwa biaya pemeliharaan mencakup persentase besar dari total biaya operasional, sehingga sangat wajar untuk memasukkan kegiatan pemeliharaan dalam jadwal (Yoo \& Lee, 2016; 
Gustavsson, Patriksson, Strömberg, 1960), setiap penggantian item dapat Wojciechowski, \& Önnheim, 2014). diperhitungkan, kerusakan dapat dibatasi, Dalam jadwal perawatan kendaraan yang perawatan dilakukan secara berkala, dapat dilakukan secara berkala pada setiap memprediksi jumlah perbaikan dan kendaraan sangatlah berbeda-beda petunjuk waktu, mengurangi konsep penanganannya, dilihat dari segi merk, perbaikan dan pemeliharaan yang tidak type/jenis kendaraan, serta jarak tempuh sempurna (Pham \& Wang, 1996), akan pada kendaraan itu sendiri.

\section{Preventive Maintenance}

(PM),

Corrective Maintenance (CM), (Lin, Huang, \& Fang, 2015; Wang, 2002; Valdez-Flores \& Feldman, 1989), dan Schedule Preventive Maintenance (SPM) (Asti \& Prasetyawan, 2013) merupakan suatu metode pemeliharaan untuk dapat menentukan penjadwalan kendaraan secara tepat dan akurat. Preventive maintenance (PM) adalah pemeliharaan yang terjadi ketika sebuah system masih beroperasi. Menurut MIL-STD-721B, PM dapat diartikan suatu tindakan yang dilakukan dalam upaya untuk mempertahankan item dalam kondisi tertentu dengan menyediakan pemeriksaan sistematis, deteksi, dan pencegahan kegagalan yang akan baru terjadi. Corrective maintenance (CM) adalah pemeliharaan yang terjadi ketika sistem gagal disebut juga dengan breakdown atau run to failure maintenance. Menurut MIL-STD- 721B, $\mathrm{CM}$ sebagai perbaikan atau tindakan yang dilakukan akibat dari kegagalan, untuk mengembalikan item kekondisi yang ditentukan. Schedule preventive maintenance (SPM) adalah suatu tindakan pemeliharaan yang dilakukan secara terjadwal dalam upaya reliable item yang diganti atau masih bisa digunakan (belum mencapai batas masa hidupnya).

PM memiliki kelebihan penggantian unit selalu diganti di $\mathrm{T}$ umurnya atau pada kegagalan, mana yang terlebih dahulu, di mana $\mathrm{T}$ adalah konstan (Barlow \& Hunter, tetapi PM memiliki kelemahan biaya pemeliharaan terus menerus saat fungsi dari usia unit atau banyaknya perbaikan (Pham \& Wang, 1996; Valdez-Flores \& Feldman, 1989).

CM memiliki kelebihan dapat mempelajari kualitas dari item unit, waktu usia unit dapat diketahui, dapat menganalisa sebab-sebab dari kegagalan serta cara-cara mengatasinya, perlunya perbaikan saat kondisi system breakdown atau gagal, sehingga biaya untuk perbaikan dikeluarkan pada waktu yang cukup lama.

SPM dapat memecahkan permasalah PM dan CM tersebut, yaitu pada faktor biaya yang dikeluarkan untuk perawatan atau perbaikan, perlu cepatnya menemukan material dan personil untuk reparasi, serta tidak adanya penjadwalan dalam perbaikan/pemeliharaan (Asti \& Prasetyawan, 2013), yang mana ini tepat untuk melakukan penjadwalan pemeliharaan kendaraan secara berkala pada penelitian ini. Akan tetapi SPM memiliki kelemahan pada reparasi yang dilakukan terhadap item unit bisa berpotensi breakdown, sehingga kurang efisien dalam perawatan, serta penerapan SPM hanya pada kendaraan jenis tertentu (Asti \& Prasetyawan, 2013; Zachary, 2014; Chang, 2014).

K-Means merupakamn algoritma clustering yang paling populer digunakan karena memiliki kelebihan yaitu algoritmanya sederhana, mudah di implementasikan, dan merupakan salah satu metode yang cukup efisien dalam hal 
kompleksitas nya O(nkt) (Aggarwal, Aggarwal, \& Gupta, 2012). Dengan adanya penerapan metode K-Means pada penentuan jadwal perawatan kendaraan secara berkala mampu mengatasi masalah pada PM, CM, dan SPM.

\section{PENELITIAN TERKAIT}

Model penelitian Zhao, Al-Khalifa, Magid, \& Nakagawa (2017), sebuah penelitian tentang age replacement dengan skema klasifikasi model penggantian dan perhitungan usia komponen yang dapat digunakan untuk pemeliharaan (Zhao, Alkhalifa, Magid, \& Nakagawa, 2017), klasifikasi ini dimaksud untuk membantu serta sebagai pedoman untuk mengklasifikasikan model pemeliharaan sehingga pembuat keputusan dapat mengenali model yang paling sesuai dengan masalah pemeliharaan-Nya. Random

Replacement, Replacement at time $T$ and number $N$, dan Replacement over time $T$ (Chen, Mizutani, \& Nakagawa, 2010) merupakan tiga jenis model pemeliharaan Age Replacement (AR) yang sering digunakan dalam pemeliharaan. Metode ini sangat populer digunakan sejak pertama kali diperkenalkan oleh (Barlow \& Hunter, 1960).

Awalnya, kendaraan direview terlebih dahulu history servicenya, dari hasil review history tersebut, akan menyajikan data-data problem, penanganannya, serta data penggantian item komponen/spareparts. Berdasarkan data kerusakan kendaraan tersebut, dapat diketahui waktu antara tiaptiap kerusakan yang di urutkan dari yang terkecil sampai dengan yang bernilai besar (Purnama, Putra, \& Kalamollah, 2015). Setiap pengganti item komponen spareparts pada $T$ usia menjadikan titik ukur dimana $T$ adalah konstan $t 0=0$ (Barlow \& Hunter, 1960). Kemudian, sebagai konsep perbaikan yang paling sedikit dari pemeliharaan yang tidak sempurna sehingga dibutuhkan pemeliharaan berkala/periodic PM $t 0=\mathrm{T}$ (Pham \& Wang, 1996). Selanjutnya menentukan model klasifikasi perbaikan, fungsi padat probabilitas dan dilanjutkan dengan menentukan keandalan komponen, dengan demikian dapat diketahui perbaikan yang optimal.

Model penelitian Rasindyo, Kusmaningrum, \& Helianty (2015), Pada penelitian yang dilakukan oleh (Rasindyo, Kusmaningrum, \& Helianty, 2015) memperkenalkan model pemeliharaan reliability centered maintenance (RCM) dimana model pemeliharaan ini dilakukan untuk menjamin suatu asset fisik dapat berlangsung terus memenuhi dengan fungsi yang diharapkan dalam konteks suatu pendekatan pemeliharaan yang mengkombinasikan praktek dan strategi dari preventive maintenance (PM) dan corrective maintenance $(\mathrm{CM})$. Dimana implementasi RCM dapat berlangsung secara efektif dengan menganalisis 7 pertanyaan diantaranya System Function (SF), Functional Failure (FF), Failure Mode (FM), Failure Effect (FE), Failure Consequence (FC), Proactive Task and Task Interval (PTTI), dan Default Action (DA), ketujuh pertanyaan dituangkan dalam bentuk Failure Mode dan Effect Analysis (FMEA) dan RCM II Decision Diagram yang tergabung dalam RCM Worksheet (Nowlan, 1978).

Pengumpulan data kegagalan merupakan proses awal untuk penerapan RCM, selanjutnya menentukan batasan terhadap system, batasan system disini diperlukan untuk mengetahui input dan output dari system sehingga menghasilkan informasi mengenai in/out interface. Dari batasan system tersebut kemudian menentukan functional block diagram untuk mengidentifikasikan system dengan 
terperinci, fungsi system disini untuk mengtahui informasi mengenai jenis kegagalan dan kerusakan yang terjadi pada system, kemudian menentukan Failure Mode and Effect Analysis (FMEA) pada proses ini mode kegagalan dapat mencakup semua kegagalan yang mungkin terjadi serta menganalisanya. Logic Tree Analysis (LTA) disini untuk menekan suatu prioritas dan sumber daya pada setiap mode kegagalan untuk mengklasifikasikan model kegagalan karena tidaklah sama, selanjutnya proses Task Selection (TS) dilakukan untuk menentukan kebijakan yang paling mungkin serta efektif untuk setiap mode kegagalan (Syahruddin, 2013). Sehingga dari proses tersebut membuahkan hasil akhir berupa analisis task untuk menentukan analisis perbandingan kebijakan perawatan yang optimal.

Model peneltiian Asti \& Prasetyawan (2013), Sebuah penelitian yang dilakukan oleh (Asti \& Prasetyawan, 2013), melakukan sebuah pengembangan age replacement (AR) \& reliability centered maintenance (RCM) dengan menggunakan schedule preventive maintenance (SPM), dimana untuk membuat jadwal maintenance kendaraan terlebih dahulu mengidentifikasi susunan komponen mobil (block diagram). Susunan komponen digunakan untuk melihat hubungan seri-paralel antara komponen pembangun produk yang terdiri dari mesin, chassis \& body, sehingga dapat dilihat secara detail reliability item tiap-tiap komponen.

Pada perhitungan reliability ini diperlukan input parameter kerusakan komponen (etha \& beta) yang diperoleh dari hasil fitting distribusi menggunakan software weibull++6. Setelah diketahui nilai reliability dari setiap komponen, maka dapat diketahui pada periode berapa suatu komponen harus diganti. Selanjutnya dikembangkan algoritma jadwal penggantian komponen, sehingga berdasarkan algoritma jadwal penggantian maka dibuatlah jadwal penggantian untuk tiap komponen dan penentuan waktu pemeliharaannya.

\section{METODE YANG DIUSULKAN}

Kami mengusulkan sebuah metode yang disebut 2K-Means, metode ini akan digambarkan secara skematik dan disertai dengan formula perhitungan. Penulis melakukan penelitian di PT XYZ, merupakan anak perusahaan dari HIDUP BARU GROUP yang bergerak dalam bidang jasa transportasi bus pariwisata dan antar jemput karyawan. Berdiri sejak tahun 2004 silam, anak perusahaan HIDUP BARU GROUP ini bergerak pada penyewaan kendaraan (Rent A Car) khusus industry, dan sudah memiliki 4.793 unit kendaraan yang tersebar diseluruh nusantara, serta memiliki lima cabang workshop diantaranya Jakarta, Bandung, Semarang, Surabaya, \& Lampung.

Data pada penelitian ini menggunakan Dataset Eksperimen, Blok Diagram, History Service Car's, dan Interval Service yang diperoleh dari aktivitas perbaikan di PT XYZ serta yang digunakan oleh para peneliti Asti \& Prasetyawan (2013) serta J. Purnama (2015).

Dataset yang digunakan oleh penulis seperti yang ditampilkan pada Tabel 3.1. 
Tabel 3.1 Dataset Eksperimen

\begin{tabular}{|c|c|c|c|c|c|c|c|}
\hline No & Item kompoven & $\begin{array}{l}\text { Replac } \\
\text { ement }\end{array}$ & $\begin{array}{l}\text { Adjus } \\
\text { ment }\end{array}$ & $\begin{array}{l}\text { Inspec } \\
\text { tion }\end{array}$ & $\begin{array}{l}C l e 2 n \\
U_{D}\end{array}$ & $\begin{array}{l}\text { Lubri } \\
\text { cation }\end{array}$ & Repair \\
\hline 1 & Accu / Battery & 100 & 0 & 10 & 10 & 0 & 0 \\
\hline 2 & Altermator & 0 & 30 & 10 & 0 & 10 & 150 \\
\hline 3 & Air Filter & 30 & 0 & 10 & 10 & 0 & 0 \\
\hline 4 & Bearing Release & 150 & 0 & 50 & 0 & 0 & 0 \\
\hline 5 & Brake Shoe & 80 & 40 & 40 & 40 & 0 & 0 \\
\hline 6 & Brake Drum & 200 & 50 & 50 & 50 & 0 & 0 \\
\hline 3 & Brake Pad & 150 & 0 & 50 & 50 & 0 & 0 \\
\hline 8 & Brake Fhid & 50 & 0 & 10 & 20 & 0 & 0 \\
\hline 9 & $\begin{array}{l}\text { Ball Joint and } \\
\text { Boot }\end{array}$ & 250 & 0 & 40 & 0 & 0 & 0 \\
\hline 10 & Boklam Halogent & 150 & 0 & 10 & 0 & 0 & 0 \\
\hline 11 & $\begin{array}{l}\text { Bearing Thell } \\
\text { Front }\end{array}$ & 150 & 0 & 50 & 0 & 0 & 0 \\
\hline 12 & $\begin{array}{l}\text { Bearing Whell } \\
\text { Rear }\end{array}$ & 150 & 0 & 50 & 0 & 0 & 0 \\
\hline 13 & Cover Clutch & 150 & 0 & 50 & 0 & 0 & 0 \\
\hline 14 & Chutch Fluid & 50 & 0 & 10 & 50 & 0 & 0 \\
\hline 15 & Charcoal Canister & 0 & 0 & 40 & 0 & 0 & 0 \\
\hline 16 & Cross Joint Kopel & 180 & 0 & 50 & 0 & 20 & 0 \\
\hline 17 & Differential Fluid & 40 & 0 & 10 & 0 & 0 & 0 \\
\hline 18 & Diac Clutch & 150 & 0 & 50 & 0 & 0 & 0 \\
\hline 19 & Drive Beit & 100 & 0 & 20 & 0 & 0 & 0 \\
\hline 20 & $\begin{array}{l}\text { Filter Air } \\
\text { Concitioner }\end{array}$ & 50 & 0 & 10 & 10 & 0 & 0 \\
\hline 21 & Bngine Oil & 10 & 0 & 5 & 0 & 0 & 0 \\
\hline 22 & $\begin{array}{l}\text { Fuel Filter Out } \\
\text { Tank }\end{array}$ & 80 & 0 & 10 & 10 & 0 & 0 \\
\hline 23 & Injection Nozle & 0 & 100 & 20 & 0 & 0 & 0 \\
\hline 24 & Iniection Pump & 0 & 0 & 50 & 0 & 0 & 150 \\
\hline 25 & $\begin{array}{l}\text { Master Chutch } \\
\text { Cylinder Up }\end{array}$ & 150 & 50 & 20 & 50 & 0 & 0 \\
\hline 26 & $\begin{array}{l}\text { Moster Chutch } \\
\text { Cylinder Low }\end{array}$ & 150 & 0 & 20 & 50 & 0 & 0 \\
\hline 27 & $\begin{array}{l}\text { Master Brakse } \\
\text { Cylinder Up }\end{array}$ & 150 & 50 & 20 & 50 & 0 & 0 \\
\hline 28 & $\begin{array}{l}\text { Master Brake } \\
\text { Cylinder Low }\end{array}$ & 150 & 0 & 20 & 50 & 0 & 0 \\
\hline 29 & Motor Fan & 150 & 0 & 50 & 0 & 0 & 0 \\
\hline 30 & $\begin{array}{l}\text { Power Steering } \\
\text { Fluid }\end{array}$ & 50 & 0 & 20 & 50 & 0 & 0 \\
\hline 31 & Refrigerant $A C$ & 150 & 0 & 50 & 150 & 0 & 0 \\
\hline 32 & $\begin{array}{l}\text { Shock Absorber } \\
\text { Front }\end{array}$ & 200 & 0 & 50 & 0 & 0 & 0 \\
\hline 33 & $\begin{array}{l}\text { Shock Absorber } \\
\text { Rear }\end{array}$ & 200 & 0 & 50 & 0 & 0 & 0 \\
\hline 34 & Stater Asay & 0 & 0 & 50 & 0 & 0 & 100 \\
\hline 35 & Radiator Coolant & 80 & 0 & 20 & 0 & 0 & 0 \\
\hline 36 & Radiator & 0 & 0 & 10 & 0 & 0 & 150 \\
\hline 37 & Transmision Fluid & 40 & 0 & 0 & 0 & 0 & 0 \\
\hline 38 & Tire & 120 & 10 & 10 & 0 & 0 & 0 \\
\hline 39 & Timing Belt & 150 & 0 & 50 & 0 & 0 & 0 \\
\hline 40 & V-Belt & 150 & 0 & 10 & 0 & 10 & 0 \\
\hline
\end{tabular}

Model akan dibentuk dari data yang sudah diolah, dan hasil pengolahan model akan dibandingkan dengan model yang ada saat ini. Metode yang disulkan seperti pada Gambar 3.1

Proses Awal, Pada proses awal ini dataset eksperimen akan melalui beberapa proses review untuk memastikan tiap-tiap reliability item unit/spareparts yang selanjutnya akan masuk ke tahap pengolahan dengan algoritma K-Means Clustering dan K-Harmonic Means Clustering. Proses kedua yaitu Pengolahan, pada tahap ini, dataset yang sudah direview pada proses awal selanjutnya akan diolah dengan penerapan algoritma $K$-Means Clustering dan K-Harmonic Means Clustering sehingga mendapatkan hasil yang diinginkan.

Proses ketiga Evaluasi, merupakan proses evaluasi, model yang terbentuk dari penerapan algoritma K-Means Clustering dan K-Harmonic Means Clustering dan selanjutnya akan dilakukan testing dan mendapatkan hasil accuracy dan non accuracy.

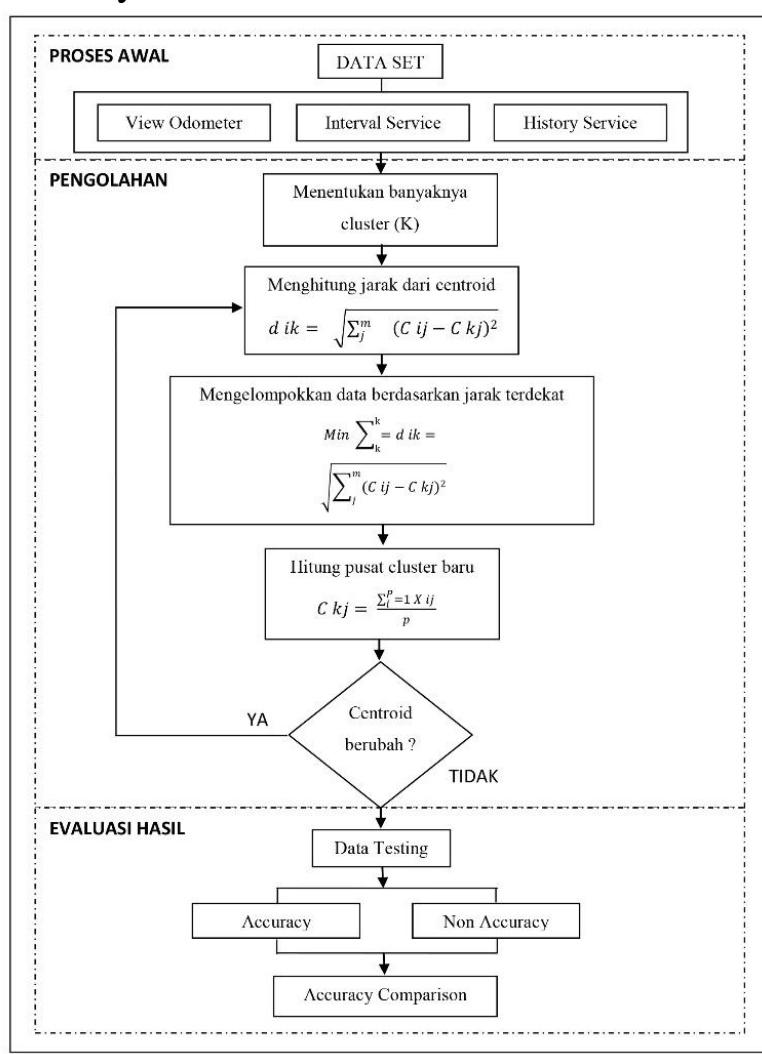

Gambar 3.1 Metode 2K-Means 
Ekperimen dan pengujian modelnya terdapat 5 tahapan, diantaranya:

1. Menyiapkan dataset untuk eksperimen.

2. Mendesain arsitektur algoritma $K$-Means Clustering dan K-Harmonic Means Clustering.

3. Melakukan data testing pada algoritma $K$-Means Clustering dan $K$ - Harmonic Means Clustering

4. Evaluasi model yang dihasilkan dari data testing sehingga mendapatkan hasil accurancy dan non accurancy.

5. Mendapatkan hasil akhir penerapan algoritma K-Means Clustering dan K- Harmonic Means Clustering.

Dalam melakukan penelitian ini, diperlukan proses pengujian eksperimen terhadap model yang diusulkan dengan menggunakan RapidMiner dan IBM SPSS Statistic. Proses eksperimen dan pengujian model ini menggunakan bagian dari dataset yang ada.

Proses keempat, evaluasi dan hasil, model yang terbentuk akan diuji dengan menggunakan confusion matrix untuk mengetahui tingkat accurancy, Tabel 3.2 merupakan tampilan dari confusion matrix. Confusion matrix akan menggambarkan hasil accurancy mulai dari prediksi positif yang benar, prediksi positif yang salah, prediksi negative yang benar, dan prediksi negative yang salah. Accuracy akan dihitung dari seluruh prediksi yang benar (baik dari prediksi positif dan negative) dibandingkan dengan seluruh data testing. Semakin tinggi nilai accuracy, semakin baik pula model yang dihasilkan.

Tabel 3.2 Confusion Matrix

\begin{tabular}{|c|c|c|c|c|}
\hline \multirow{2}{*}{\multicolumn{2}{|c|}{ Confusion Matrix }} & \multicolumn{2}{|c|}{ Target } & \\
\hline & & Positive & Negative & \multirow[b]{2}{*}{ Positive Predictive Value $a(a+b)$} \\
\hline \multirow{2}{*}{ Model } & Positive & True $(+)$ & False (+) & \\
\hline & Negative & False (-) & True $(-)$ & Negative Predictive Value $d /(c+d)$ \\
\hline & & Sensitivity & Specificity & \multirow{2}{*}{ Accuracy $=(a+d) /(a+b+c+d)$} \\
\hline & & $\mathrm{a} /(\mathrm{a}+\mathrm{c})$ & $d /(b+d)$ & \\
\hline
\end{tabular}

\section{HASIL EKSPERIMEN}

Tujuan dari penelitian ini adalah untuk mengetahui komparasi tingkat accuracy dari penerapan algoritma K-Means Clustering dan K-Harmonic Means Clustering untuk schedule preventive maintenance pada PT XYZ.

Data hasil penelitian K-Means Clustering Data dari penelitian ini pertama-tama menentukan titik pusat awal cluster seperti yang ditunjukkan pada Tabel 4.1 dibawah ini :

Tabel 4.1 Titik Pusat Awal Cluster

\begin{tabular}{|c|c|c|c|c|c|c|c|}
\hline No & Item komponen & $\begin{array}{c}\text { Replac } \\
\text { ement }\end{array}$ & $\begin{array}{c}\text { Adjus } \\
\text { ment }\end{array}$ & $\begin{array}{c}\text { Inspec } \\
\text { tion }\end{array}$ & $\begin{array}{c}\text { Clean } \\
\text { up }\end{array}$ & $\begin{array}{c}\text { Lubri } \\
\text { cation }\end{array}$ & Repair \\
\hline 21 & Engine oil & 10 & 0 & 5 & 0 & 0 & 0 \\
\hline 29 & Motor Fan & 150 & 0 & 50 & 0 & 0 & 0 \\
\hline
\end{tabular}

Dari titik pusat awal cluster, selanjutnya akan dihitung jarak pusat cluster antara data dengan pusat awal cluster dengan menggunakan persamaan Euclidean Distance seperti yang ditunjukan pada persamaan (4.1) dibawah ini:

$$
d i k=\sqrt{\sum_{j}^{m}(C i j-C k j)^{2}}
$$

Hasil perhitungan matrik jarak dapat dilihat pada Tabel 4.2 dibawah ini : 
Tabel 4.2 Hasil Perhitungan Matrik Jarak

\begin{tabular}{|c|c|c|c|}
\hline No & \begin{tabular}{|c|}
$\begin{array}{c}\text { Jarak Data Ke Pusat } \\
\text { Cluster }\end{array}$ \\
\end{tabular} & Cluster I & Cluster 2 \\
\hline 1 & $\begin{array}{c}\text { Jarak data ke-1 pusat } \\
\text { cluster }\end{array}$ & 90.7 & 63.25 \\
\hline 2 & \begin{tabular}{|c|}
$\begin{array}{c}\text { Jarak data ke-2 pusat } \\
\text { cluster }\end{array}$ \\
\end{tabular} & 153.05 & 24.5 \\
\hline 3 & \begin{tabular}{|c|}
$\begin{array}{c}\text { Jarak data ke-3 pusat } \\
\text { cluster }\end{array}$ \\
\end{tabular} & 22.91 & 126.1 \\
\hline 4 & \begin{tabular}{|c|}
$\begin{array}{c}\text { Jarak data ke-4 pusat } \\
\text { cluster }\end{array}$ \\
\end{tabular} & 147.05 & 0 \\
\hline 5 & \begin{tabular}{|c|}
$\begin{array}{c}\text { Jarak data ke-5 pusat } \\
\text { cluster }\end{array}$ \\
\end{tabular} & 96.6 & 52.92 \\
\hline \begin{tabular}{|l|}
6 \\
\end{tabular} & $\begin{array}{c}\text { Jarak data ke-6 pusat } \\
\text { cluster }\end{array}$ & 207.7 & 86.60 \\
\hline \begin{tabular}{|l|}
7 \\
\end{tabular} & \begin{tabular}{|c|}
$\begin{array}{c}\text { Jarak data ke- } 7 \text { pusat } \\
\text { cluster }\end{array}$ \\
\end{tabular} & 155.32 & 50 \\
\hline 8 & $\begin{array}{c}\text { Jarak data ke-8 pusat } \\
\text { cluster }\end{array}$ & 45 & 105.83 \\
\hline 9 & \begin{tabular}{|c|}
$\begin{array}{c}\text { Jarak data ke-9 pusat } \\
\text { cluster }\end{array}$ \\
\end{tabular} & 242.54 & 99.5 \\
\hline 10 & \begin{tabular}{|c|}
$\begin{array}{c}\text { Jarak data ke-10 pusat } \\
\text { cluster }\end{array}$ \\
\end{tabular} & 140.1 & 40 \\
\hline 11 & $\begin{array}{c}\text { Jarak data ke-11 pusat } \\
\text { cluster }\end{array}$ & 147.05 & 0 \\
\hline \begin{tabular}{|l|}
12 \\
\end{tabular} & \begin{tabular}{|c|}
$\begin{array}{c}\text { Jarak data ke-12 pusat } \\
\text { cluster }\end{array}$ \\
\end{tabular} & 147.05 & 0 \\
\hline \begin{tabular}{|l|}
13 \\
\end{tabular} & \begin{tabular}{|c|}
$\begin{array}{c}\text { Jarak data ke-13 pusat } \\
\text { cluster }\end{array}$ \\
\end{tabular} & 151.74 & 0 \\
\hline 14 & \begin{tabular}{|c|}
$\begin{array}{c}\text { Jarak data ke-14 pusat } \\
\text { cluster }\end{array}$ \\
\end{tabular} & 64.23 & 95.4 \\
\hline
\end{tabular}

\begin{tabular}{|c|c|c|c|}
\hline 15 & \begin{tabular}{|c|} 
Jarak data ke-15 pusat \\
cluster
\end{tabular} & 33.54 & 150.33 \\
\hline 16 & $\begin{array}{c}\text { Jarak data ke-16 pusat } \\
\text { cluster }\end{array}$ & 176.98 & 36.05 \\
\hline 17 & $\begin{array}{c}\text { Jarak data ke-17 pusat } \\
\text { cluster }\end{array}$ & 30.41 & 117.05 \\
\hline 18 & Jarak data ke-18 pusat & 140.1 & 0 \\
\hline 19 & $\begin{array}{c}\text { Jarak data ke-19 pusat } \\
\text { cluster }\end{array}$ & 91.24 & 58.31 \\
\hline 20 & $\begin{array}{c}\text { Jarak data ke-20 pusat } \\
\text { cluster }\end{array}$ & 41.53 & 107.24 \\
\hline 21 & $\begin{array}{c}\text { Jarak data ke-21 pusat } \\
\text { cluster }\end{array}$ & 0 & 147.054412 \\
\hline 22 & $\begin{array}{c}\text { Jarak data ke- } 22 \text { pusat } \\
\text { cluster }\end{array}$ & 70.9 & 80 \\
\hline 23 & $\begin{array}{c}\text { Jarak data ke-23 pusat } \\
\text { cluster }\end{array}$ & 100.62 & 115.8 \\
\hline 24 & $\begin{array}{c}\text { Jarak data ke-24 pusat } \\
\text { cluster }\end{array}$ & 157.8 & 0 \\
\hline 25 & $\begin{array}{c}\text { Jarak data ke-25 pusat } \\
\text { cluster }\end{array}$ & 157.6 & 64.03 \\
\hline 26 & $\begin{array}{c}\text { Jarak data ke-26 pusat } \\
\text { cluster }\end{array}$ & 149.41 & 40 \\
\hline 27 & $\begin{array}{c}\text { Jarak data ke-27 pusat } \\
\text { cluster }\end{array}$ & 157.6 & 64.03 \\
\hline 28 & $\begin{array}{c}\text { Jarak data ke-28 pusat } \\
\text { cluster }\end{array}$ & 149.41 & 40 \\
\hline 29 & $\begin{array}{c}\text { Jarak data ke-29 pusat } \\
\text { cluster }\end{array}$ & 147.05 & 0 \\
\hline 30 & $\begin{array}{c}\text { Jarak data ke-30 pusat } \\
\text { cluster }\end{array}$ & 65.8 & 91.7 \\
\hline 31 & $\begin{array}{c}\text { Jarak data ke-31 pusat } \\
\text { cluster }\end{array}$ & 210.1 & 150 \\
\hline 32 & $\begin{array}{c}\text { Jarak data ke-32 pusat } \\
\text { cluster }\end{array}$ & 195.3 & 50 \\
\hline 33 & $\begin{array}{c}\text { Jarak data ke-33 pusat } \\
\text { cluster }\end{array}$ & 195.3 & 50 \\
\hline 34 & $\begin{array}{c}\text { Jarak data ke-34 pusat } \\
\text { cluster }\end{array}$ & 109.20 & 111.80 \\
\hline
\end{tabular}

Dari hasil perhitungan matrik jarak akan dilakukan perbandingan dan dipilih jarak yang paling dekat antara data dengan pusat cluster, jarak ini akan menunjukkan bahwa data yang memiliki jarak terdekat berada dalam satu kelompok dengan pusat cluster terdekat, pengelompokkan data tersebut dapat dilihat pada Tabel 4.3 di bawah ini. Jarak terdekat untuk cluster 1 berarti data tersebut berada dalam kelompok 1, dan cluster 2 berarti data tersebut berada dalam kelompok 2 . 
Tabel 4.3 Pengelompokan Data

\begin{tabular}{|c|c|c|c|c|}
\hline No & Data Ke & Cluster 1 & Cluster 2 & Jarak Terdekat \\
\hline 1 & 1 & 90.7 & 63.25 & Cluster 2 \\
\hline 2 & 2 & 153.05 & 24.5 & Cluster 2 \\
\hline 3 & 3 & 22.91 & 126.1 & Cluster 1 \\
\hline 4 & 4 & 147.05 & 0 & Cluster 2 \\
\hline 5 & 5 & 96.6 & 52.92 & Cluster 2 \\
\hline 6 & 6 & 207.7 & 86.60 & Cluster 2 \\
\hline 7 & 7 & 155.32 & 50 & Cluster 2 \\
\hline 8 & 8 & 45 & 105.83 & Cluster 1 \\
\hline 9 & 9 & 242.54 & 99.5 & Cluster 2 \\
\hline
\end{tabular}

\begin{tabular}{|c|c|c|c|c|}
\hline 10 & 10 & 140.1 & 40 & Cluater 2 \\
\hline 11 & 11 & 147.05 & 0 & Cluater 2 \\
\hline 12 & 12 & 147.05 & 0 & Cluater 2 \\
\hline 13 & 13 & 151.74 & 0 & Cluater 2 \\
\hline 14 & 14 & 64.23 & 95.4 & Cluater 1 \\
\hline 15 & 15 & 33.54 & 150.33 & Cluater 1 \\
\hline 16 & 16 & 176.98 & 36.05 & Cluater 2 \\
\hline 17 & 17 & 30.41 & 117.05 & Cluater 1 \\
\hline 18 & 18 & 140.1 & 0 & Cluater 2 \\
\hline 19 & 19 & 91.24 & 58.31 & Cluater 2 \\
\hline 20 & 20 & 41.53 & 107.24 & Cluater 1 \\
\hline 21 & 21 & 0 & 147.054412 & Cluater 1 \\
\hline 22 & 22 & 70.9 & 80 & Cluater 1 \\
\hline 23 & 23 & 100.62 & 115.8 & Cluater 1 \\
\hline 24 & 24 & 157.8 & 0 & Cluater 2 \\
\hline 25 & 25 & 157.6 & 64.03 & Cluater 2 \\
\hline 26 & 26 & 149.41 & 40 & Cluater 2 \\
\hline 27 & 27 & 157.6 & 64.03 & Cluater 2 \\
\hline 28 & 28 & 149.41 & 40 & Cluater 2 \\
\hline 29 & 29 & 147.05 & 0 & Cluater 2 \\
\hline 30 & 30 & 65.8 & 91.7 & Cluater 1 \\
\hline 31 & 31 & 210.1 & 150 & Cluater 2 \\
\hline 32 & 32 & 195.3 & 50 & Cluater 2 \\
\hline 33 & 33 & 195.3 & 50 & Cluater 2 \\
\hline 34 & 34 & 109.20 & 111.80 & Cluater 1 \\
\hline 35 & 35 & 71.6 & 76.2 & Cluater 1 \\
\hline 36 & 36 & 149.75 & 40 & Cluater 2 \\
\hline 37 & 37 & 29.6 & 120.83 & Cluater 1 \\
\hline 38 & 38 & 110.6 & 48.98 & Cluater 2 \\
\hline 39 & 39 & 147.05 & 0 & Cluater 2 \\
\hline 40 & 40 & 140.44 & 38.73 & Cluater 2 \\
\hline
\end{tabular}


Berdasarkan matrik yang didapatkan pada tabel di atas maka didapatkan pengelompokkan yang ditampilkan pada Tabel 4.4 sebagai berikut :

Tabel 4.4 Hasil Pengelompokkan Data

\begin{tabular}{|c|l|}
\hline Cluster1 & $\begin{array}{l}\text { Data 3, 8, 14, 15, 17, 20, 21, 22, 23, 30, 34, 35, } \\
\text { dan 37 }\end{array}$ \\
\hline & $\begin{array}{l}\text { Data 1, 2, 4, 5, 6, 7, 9, 10, 11, 12, 13, 16, 18, 19, } \\
\text { Cluster2 } \\
24,25,26,27,28,29,31,32,33,36,38,39, \text { dan } \\
40\end{array}$ \\
\hline
\end{tabular}

Setelah didapatkan anggota dari setiap cluster kemudian akan di tentukan pusat cluster baru yang di hitung berdasarkan data anggota tiap-tiap cluster seperti yang ditunjukan pada persamaan (4.2):

$$
C k j=\frac{\sum_{i}^{P}=1 \times i j}{p}
$$

Dari perhitungan menggunakan persamaan 4.2 di atas, maka didapatkan hasil pusat cluster dalam matrik pusat cluster baru yang dapat dilihat pada Tabel 4.5 dibawah ini:

Tabel 4.5 Pusat Cluster Baru Algoritma KMeans Clustering

\begin{tabular}{|l|c|c|c|c|c|l|}
\hline Cluster1 & 36.92 & 7.7 & 16.54 & 11.54 & 0 & 7.7 \\
\hline Cluster2 & 136.3 & 8.52 & 34.81 & 18.52 & 1.5 & 16.7 \\
\hline
\end{tabular}

Dataset pada penelitian ini akan diterapkan pendekatan algoritma KHarmonic Means Clustering, dengan proses awal inisialisasi titik centroid sebanyak jumlah cluster secara random, yang ditampilkan pada Tabel 4.6

dibawah ini:
Tabel 4.6 Inisialisasi Titik Centroid

\begin{tabular}{|c|c|c|c|c|c|c|c|}
\hline No & Item komponen & $\begin{array}{c}\text { Replac } \\
\text { ement }\end{array}$ & $\begin{array}{c}\text { Adjus } \\
\text { ment }\end{array}$ & $\begin{array}{c}\text { Inspec } \\
\text { tion }\end{array}$ & $\begin{array}{c}\text { Clean } \\
\text { up }\end{array}$ & $\begin{array}{c}\text { Lubri } \\
\text { cation }\end{array}$ & $\begin{array}{c}\text { Repai } \\
\text { I }\end{array}$ \\
\hline 21 & Engine oil & 10 & 0 & 5 & 0 & 0 & 0 \\
\hline 29 & Motor Fan & 150 & 0 & 50 & 0 & 0 & 0 \\
\hline
\end{tabular}

Dari penentuan inisialisasi titik centroid pada cluster secara random, selanjutnya hitung nilai fungsi anggota cluster atau Objective Function yang mendefinisikan proporsi dari data point $\mathrm{Xi}$ milik pusat $\mathrm{Cl}$ dengan persamaan (4.3)

$$
K H M(X, C)=\sum_{i=1}^{N} \frac{K}{\sum_{i=l \mid \frac{1}{|X i-C l|^{p}}}^{K}}
$$

Hasil perhitungan untuk nilai fungsi tujuan ke-22 ...... N terhadap dataset yang dapat dilihat pada Tabel 4.7 dibawah ini :

Tabel 4.7 Hasil Perhitungan Objective Function

\begin{tabular}{|c|c|c|}
\hline No & Nilai Fungsi Ke Dataset & Nilai \\
\hline 1 & Nilai fungsi pada dataset ke 1 & 28.6 \\
\hline 2 & Nilai fungsi pada dataset ke 2 & 29.03 \\
\hline 3 & Nilai fungsi pada dataset ke 3 & 24 \\
\hline 4 & Nilai fungsi pada dataset ke 4 & 225 \\
\hline 5 & Nilai fungsi pada dataset ke 5 & 68.6 \\
\hline
\end{tabular}




\begin{tabular}{|c|l|c|}
\hline 6 & Nilai fungsi pada dataset ke 6 & 92.31 \\
\hline 7 & Nilai fungsi pada dataset ke 7 & 128.6 \\
\hline 8 & Nilai fungsi pada dataset ke 8 & 35.3 \\
\hline 9 & Nilai fungsi pada dataset ke 9 & 206.9 \\
\hline 10 & Nilai fungsi pada dataset ke 10 & 56.25 \\
\hline 11 & Nilai fungsi pada dataset ke 11 & 225 \\
\hline 12 & Nilai fungsi pada dataset ke 12 & 225 \\
\hline 13 & Nilai fungsi pada dataset ke 13 & 225 \\
\hline 14 & Nilai fungsi pada dataset ke 14 & 42.9 \\
\hline 15 & Nilai fungsi pada dataset ke 15 & 240 \\
\hline 16 & Nilai fungsi pada dataset ke 16 & 79.41 \\
\hline 17 & Nilai fungsi pada dataset ke 17 & 48 \\
\hline 18 & Nilai fungsi pada dataset ke 18 & 225 \\
\hline 19 & Nilai fungsi pada dataset ke 19 & 100 \\
\hline 20 & Nilai fungsi pada dataset ke 20 & 50 \\
\hline 21 & Nilai fungsi pada dataset ke 21 & 20 \\
\hline 22 & Nilai fungsi pada dataset ke 22 & 28.23 \\
\hline 23 & Nilai fungsi pada dataset ke 23 & 100 \\
\hline 24 & Nilai fungsi pada dataset ke 24 & 150 \\
\hline 25 & Nilai fungsi pada dataset ke 25 & 62.1 \\
\hline 26 & Nilai fungsi pada dataset ke 26 & 78.3 \\
\hline 27 & Nilai fungsi pada dataset ke 27 & 62.1 \\
\hline
\end{tabular}

\begin{tabular}{|c|c|c|}
\hline 28 & Nilai fungsi pada dataset ke 28 & 78.3 \\
\hline 29 & Nilai fungsi pada dataset ke 29 & 225 \\
\hline 30 & Nilai fungsi pada dataset ke 30 & 66.7 \\
\hline 31 & Nilai fungsi pada dataset ke 31 & 225 \\
\hline 32 & Nilai fungsi pada dataset ke 32 & 240 \\
\hline 33 & Nilai fungsi pada dataset ke 33 & 240 \\
\hline 34 & Nilai fungsi pada dataset ke 34 & 200 \\
\hline 35 & Nilai fungsi pada dataset ke 35 & 80 \\
\hline 36 & Nilai fungsi pada dataset ke 36 & 56.25 \\
\hline 37 & Nilai fungsi pada dataset ke 37 & 240 \\
\hline 38 & Nilai fungsi pada dataset ke 38 & 28.8 \\
\hline 39 & Nilai fungsi pada dataset ke 39 & 225 \\
\hline 40 & Nilai fungsi pada dataset ke 40 & 29.03 \\
\hline
\end{tabular}

Dari perhitungan fungsi anggota atau objective function diatas, peneliti mendapatkan nilai fungsi dari tiap-tiap dataset, yang selanjutnya nilai tersebut akan dikelompokkan sesuai inisialisasi penentuan titik cluster awal dengan jarak terdekat, dimana data dari dataset ke 21 disebut sebagai KHM 1 dan data dari dataset ke 29 disebut sebagai KHM 2. Maka diketahuilah dari nilai fungsi pada dataset tersebut akan masuk pada tiap-tiap anggota cluster yang dapat dilihat pada Tabel 4.8 dibawah ini:

Tabel 4.8 Jarak Terdekat Nilai Fungsi Dataset

\begin{tabular}{|c|c|c|c|}
\hline No & Nilai Fungsi Ke Dataset & Nilai & $\begin{array}{c}\text { Anggota } \\
\text { Cluster }\end{array}$ \\
\hline 1 & $\begin{array}{c}\text { Nilai fungsi pada dataset } \\
\text { ke } 1\end{array}$ & 28.6 & KHM1 \\
\hline 2 & $\begin{array}{c}\text { Nilai fungsi pada dataset } \\
\text { ke 2 }\end{array}$ & 29.03 & KHM1 \\
\hline 3 & $\begin{array}{c}\text { Nilai fungsi pada dataset } \\
\text { ke 3 }\end{array}$ & 24 & KHM1 \\
\hline 4 & $\begin{array}{c}\text { Nilai fungsi pada dataset } \\
\text { ke 4 }\end{array}$ & 225 & KHM2 \\
\hline 5 & $\begin{array}{c}\text { Nilai fungsi pada dataset } \\
\text { ke 5 }\end{array}$ & 68.6 & KHM1 \\
\hline
\end{tabular}




\begin{tabular}{|c|c|c|c|}
\hline 6 & $\begin{array}{c}\text { Nilai fungsi pada dataset } \\
\text { ke } 6\end{array}$ & 92.31 & KHM1 \\
\hline 7 & $\begin{array}{c}\text { Nilai fungsi pada dataset } \\
\text { ke } 7\end{array}$ & 128.6 & KHM1 \\
\hline 8 & $\begin{array}{l}\text { Nilai fungsi pada dataset } \\
\text { ke } 8\end{array}$ & 35.3 & KHM1 \\
\hline 9 & $\begin{array}{l}\text { Nilai fungsi pada dataset } \\
\text { ke } 9\end{array}$ & 206.9 & KHM2 \\
\hline 10 & $\begin{array}{c}\text { Nilai fungsi pada dataset } \\
\text { ke } 10\end{array}$ & 56.25 & KHM1 \\
\hline 11 & $\begin{array}{c}\text { Nilai fungsi pada dataset } \\
\text { ke } 11\end{array}$ & 225 & KHM2 \\
\hline 12 & $\begin{array}{l}\text { Nilai fungsi pada dataset } \\
\text { ke } 12\end{array}$ & 225 & KHM2 \\
\hline 13 & $\begin{array}{c}\text { Nilai fungsi pada dataset } \\
\text { ke } 13\end{array}$ & 225 & KHM2 \\
\hline 14 & $\begin{array}{c}\text { Nilai fungsi pada dataset } \\
\text { ke } 14\end{array}$ & 42.9 & KHM1 \\
\hline 15 & $\begin{array}{l}\text { Nilai fungsi pada dataset } \\
\text { ke } 15\end{array}$ & 240 & KHM2 \\
\hline 16 & $\begin{array}{c}\text { Nilai fungsi pada dataset } \\
\text { ke } 16\end{array}$ & 79.41 & KHM1 \\
\hline 17 & $\begin{array}{c}\text { Nilai fungsi pada dataset } \\
\text { ke } 17\end{array}$ & 48 & KHM1 \\
\hline 18 & $\begin{array}{c}\text { Nilai fungsi pada dataset } \\
\text { ke } 18\end{array}$ & 225 & KHM2 \\
\hline 19 & $\begin{array}{c}\text { Nilai fungsi pada dataset } \\
\text { ke } 19\end{array}$ & 100 & KHM1 \\
\hline 20 & $\begin{array}{c}\text { Nilai fungsi pada dataset } \\
\text { ke } 20\end{array}$ & 50 & KHM1 \\
\hline 21 & $\begin{array}{c}\text { Nilai fungsi pada dataset } \\
\text { ke } 21\end{array}$ & 20 & KHM1 \\
\hline 22 & $\begin{array}{c}\text { Nilai fungsi pada dataset } \\
\text { ke } 22\end{array}$ & 28.23 & KHM1 \\
\hline 23 & $\begin{array}{c}\text { Nilai fungsi pada dataset } \\
\text { ke } 23\end{array}$ & 100 & KHM1 \\
\hline 24 & $\begin{array}{c}\text { Nilai fungsi pada dataset } \\
\text { ke } 24\end{array}$ & 150 & KHM2 \\
\hline 25 & $\begin{array}{c}\text { Nilai fungsi pada dataset } \\
\text { ke } 25\end{array}$ & 62.1 & KHM1 \\
\hline 26 & $\begin{array}{c}\text { Nilai fungsi pada dataset } \\
\text { ke } 26\end{array}$ & 78.3 & KHM1 \\
\hline 27 & $\begin{array}{c}\text { Nilai fungsi pada dataset } \\
\text { ke } 27\end{array}$ & 62.1 & KHM1 \\
\hline 28 & $\begin{array}{c}\text { Nilai fungsi pada dataset } \\
\text { ke } 28\end{array}$ & 78.3 & KHM1 \\
\hline 29 & $\begin{array}{c}\text { Nilai fungsi pada dataset } \\
\text { ke } 29\end{array}$ & 225 & KHM2 \\
\hline 30 & $\begin{array}{c}\text { Nilai fungsi pada dataset } \\
\text { ke } 30\end{array}$ & 66.7 & KHM1 \\
\hline 31 & $\begin{array}{c}\text { Nilai fungsi pada dataset } \\
\text { ke } 31\end{array}$ & 225 & KHM2 \\
\hline 32 & $\begin{array}{c}\text { Nilai fungsi pada dataset } \\
\text { ke } 32\end{array}$ & 240 & KHM2 \\
\hline 33 & $\begin{array}{c}\text { Nilai fungsi pada dataset } \\
\text { ke } 33\end{array}$ & 240 & KHM2 \\
\hline 34 & $\begin{array}{c}\text { Nilai fungsi pada dataset } \\
\text { ke } 34\end{array}$ & 200 & KHM2 \\
\hline 35 & $\begin{array}{c}\text { Nilai fungsi pada dataset } \\
\text { ke } 35\end{array}$ & 80 & KHM1 \\
\hline
\end{tabular}

\begin{tabular}{|c|c|c|c|}
\hline 36 & $\begin{array}{c}\text { Nilai fungsi pada dataset } \\
\text { ke } 36\end{array}$ & 56.25 & KHM1 \\
\hline 37 & $\begin{array}{c}\text { Nilai fungsi pada dataset } \\
\text { ke } 37\end{array}$ & 240 & KHM2 \\
\hline 38 & $\begin{array}{c}\text { Nilai fungsi pada dataset } \\
\text { ke } 38\end{array}$ & 28.8 & KHM1 \\
\hline 39 & $\begin{array}{c}\text { Nilai fungsi pada dataset } \\
\text { ke } 39\end{array}$ & 225 & KHM2 \\
\hline 40 & $\begin{array}{c}\text { Nilai fungsi pada dataset } \\
\text { ke } 40\end{array}$ & 29.03 & KHM1 \\
\hline
\end{tabular}

Berdasarkan jarak terdekat nilai fungsi dataset yang didapatkan pada Tabel 4.8 di atas, maka diketahui keanggotaan pada setiap pusat cluster yang ditampilkan pada Tabel 4.9 berikut ini:

Tabel 4.9 Hasil Pengelompokkan Data

\begin{tabular}{|c|c|}
\hline \multirow{3}{*}{ KHM1 } & $\begin{array}{c}1,2,3,5,6,8,10,14,16,17,20,21, \\
22,25,26,27,28,30,35,36, \\
38, \text { dan } 40\end{array}$ \\
\hline \multirow{2}{*}{ KHM2 } & $\begin{array}{c}4,7,9,11,12,13,15,18,19,23,24,29, \\
31,32,33,34,37, \text { dan } 39\end{array}$ \\
\hline
\end{tabular}

Setelah didapatkan keanggotaan pengelompokan data dari setiap cluster kemudian akan di tentukan nilai bobot $\mathrm{W}(\mathrm{Xi})$ berdasarkan persamaan (4.4)

$$
W(x i)=\frac{\sum_{l=1}^{k}\|x i-c l\|^{-p-2}}{\left(\sum_{l=1}^{k}\|x i-c l\|^{-p}\right)^{2}}
$$

Hasil perhitungan dari nilai bobot $\mathrm{W}(\mathrm{Xi})$ yang mendifinisikan seberapa besar pengaruh data point $\mathrm{Xi}$ sehingga ditetapkan keanggotaan data $\mathrm{Xi}$ pada suatu cluster dengan titik pusat cluster yang dapat dilihat pada Tabel 4.10 dibawah ini:

Tabel 4.10 Nilai Fungsi bobot $X i$

\begin{tabular}{|c|c|}
\hline & $\begin{array}{c}\text { Nilai Titik Pusat } \\
\text { Cluster }\end{array}$ \\
\hline K-Harmonic Means 1 & $\mathbf{5 2 . 0 1}$ \\
\hline K-Harmonic Means 2 & $\mathbf{2 0 2 . 5 3}$ \\
\hline
\end{tabular}


Data dari hasil penelitian ini, akan di implementasikan menggunakan RapidMiner untuk pemodelan algoritma K-Means Clustering, yang ditampilkan pada Gambar 4.1 dibawah ini:

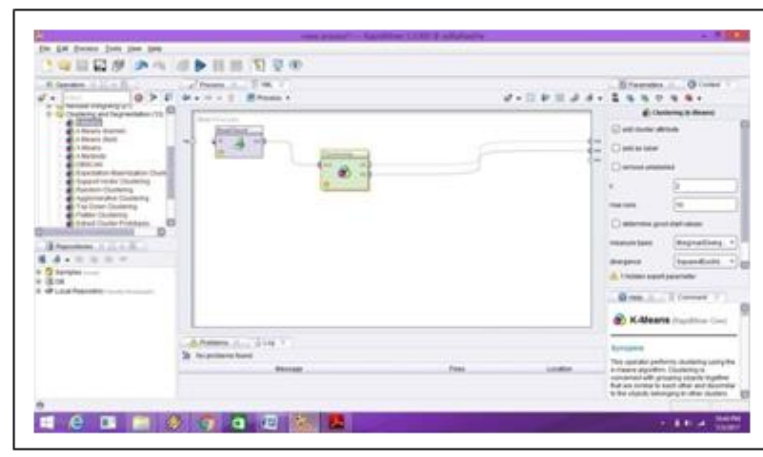

Gambar 4.1 Implementasi Dataset K-Means pada RapidMiner

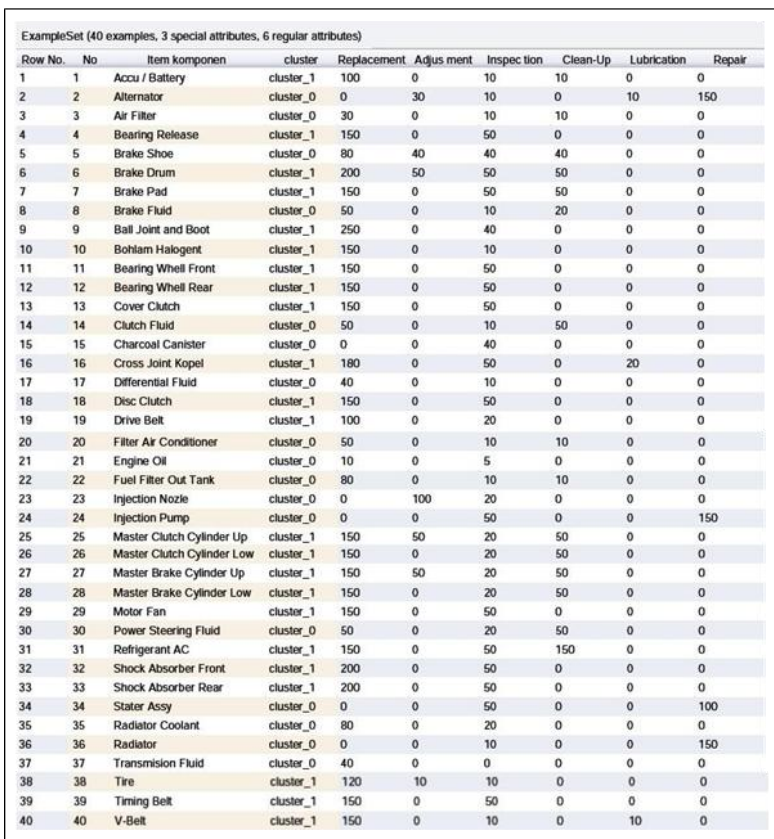

Gambar 4.2 Inisialisasi Cluster pada Dataset

Gambar 4.2 adalah hasil inisialisasi cluster yang diimplementasikan pada RapidMiner. Dengan inisialisasi jumlah cluster sebanyak 2 buah, maka didapatlah hasil dengan cluster yang terbentuk adalah 2 sesuai dengan pendefinisian nilai $K$ maka jumlah cluster_0 ada 17 item dan cluster_1 ada 23 item dengan total jumlah data sebanyak 40 item yang dapat dilihat pada data hasil cluster model K-Means Gambar 4.3 dibawah ini:

\section{Cluster Model}

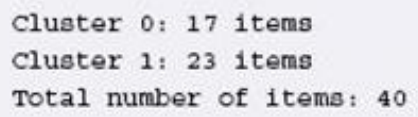

Gambar 4.3 Hasil Data Cluster Model KMeans

Dari data hasil cluster model $K$-Means dalam implementasi RapidMiner, didapatilah hasil antara jarak cluster dan centroid dari tiap-tiap attribute. Dimana nilai attribute yang memiliki nilai cluster tertinggi yaitu Replacemen dan Insepction pada cluster_1 dan Replacemen dan Repair pada cluster_0, dengan nilai yang bisa dilihat pada Tabel 4.11 dibawah ini:

4.11 Hasil Perhitungan anatara Jarak Cluster dan Centroid

\begin{tabular}{|c|c|c|}
\hline Attribute & cluster_0 & cluster_1 \\
\hline Replacemen & 32.941 & 156.522 \\
\hline Adjus ment & 10 & 6.957 \\
\hline Inspec tion & 19.118 & 36.087 \\
\hline Clean-Up & 11.176 & 20 \\
\hline Lubrication & 0.588 & 1.304 \\
\hline Repair & 32.353 & 0 \\
\hline
\end{tabular}

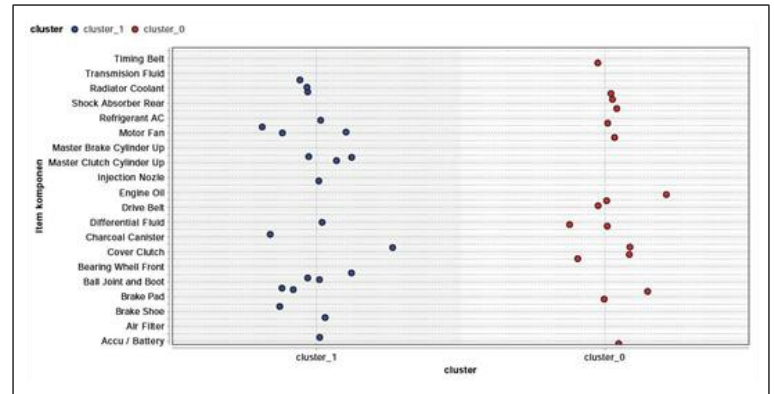

Gambar 4.4 Titik-titik Centroid Cluster Berdasarkan Item Komponen 
Gambar 4.4 adalah jarak antara titik centorid ke titik-titik centroid lainnya berdasarkan tiap-tiap item komponen, dimana cluster_1 mendominasi titik yang memiliki jarak terdekat antara item komponen dibandingkan dengan cluster_0.

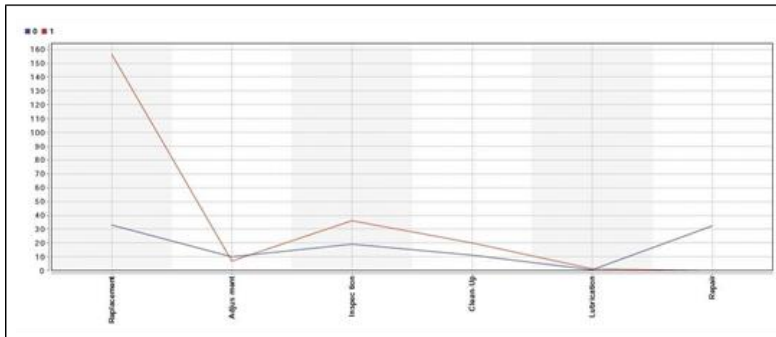

Gambar 4.5 Grafik Data Attribute K-Means Clustering

Gambar 4.5 adalah Grafik data attribute KMeans clustering dari tiap-tiap cluster, yang diperoleh dari hasil perhitungan antara jarak cluster dan centroid disajikan pada Tabel 4.11. Dimana cluster_0 memiliki 2 attribute yaitu Replacement dan Repair yang memiliki nilai tertinggi pada angka $32.9 \%$ dan $32.3 \%$. Sedangkan untuk cluster_1 memiliki 2 attribute yang berbada dengan cluster_0 yaitu Replacement dan Inspection yang memiliki nilai tertinggi pada $156.5 \%$ dan $36 \%$.

Peneliti selanjutnya melakukan pengujian dengan mengukur tingkat accuracy dengan menggunakan Confucion Matrix dari data hasil prediksi positive yang benar sebesar 220.87, prediksi positive yang salah sebesar 80.4 , prediksi negative yang benar sebesar 106.176, dan prediksi negative yang salah 216.35 seperti yang ditampilkan pada Tabel 4.12 dibawah ini :

Tabel 4.12 Nilai-nilai Prediksi

\begin{tabular}{|c|c|c|c|}
\cline { 3 - 4 } \multicolumn{2}{c|}{} & \multicolumn{2}{|c|}{ Target } \\
\cline { 3 - 4 } Model & Positive & Negative \\
\cline { 3 - 4 } & Nesitive & 220.87 & 80.4 \\
\hline
\end{tabular}

Tabel nilai hasil prediksi dapat di ketahui dengan jelas nilai dari masing-masing prediksinya yang dapat dilihat pada Tabel 4.13 dibawah ini:

Tabel 4.13 Nilai Hasil Prediksi

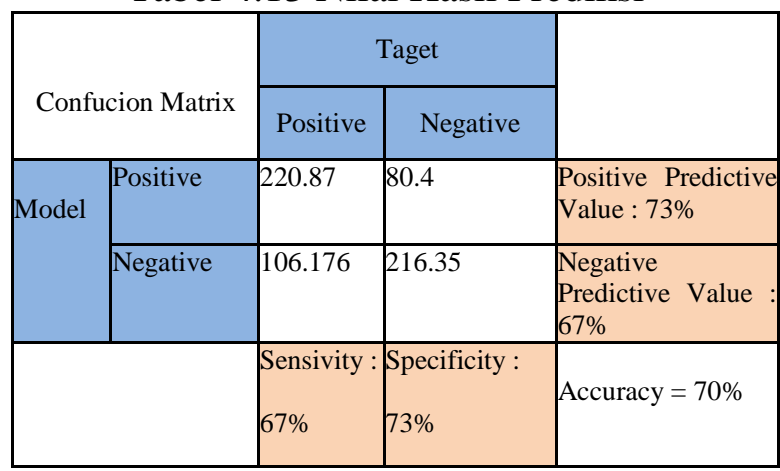

Hasil pengolahan data dengan IMB SPSS Statistic pada pengolahan algoritma KHarmonic Means Clustering yang dapat dilihat pada Gambar 4.6 dibawah ini:

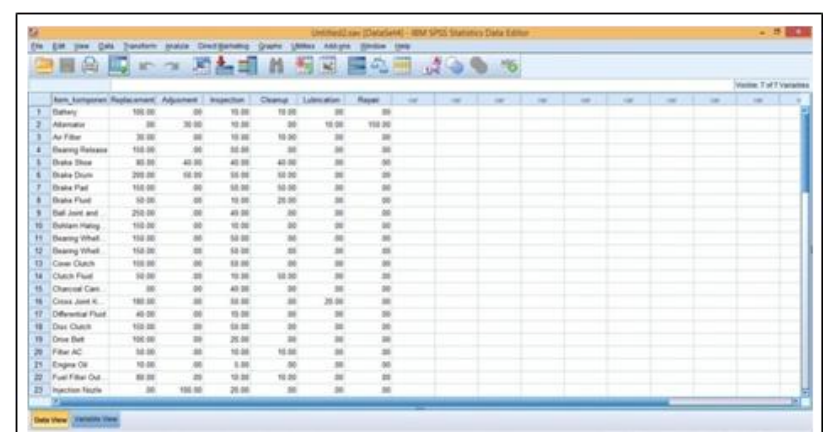

Gambar 4.6 Implementasi Dataset KHarmonic Means ke IBM SPSS Statistic

Dari hasil implementasi IBM SPSS statistic diatas didapati hasil deskripsi statistic dari K-Harmonic Means clustering untuk mengetahui nilai Mean dan Standar Deviasi. Dimana K-Harmonic Means1 memiliki data statistic untuk nilai Mean 211.5100 dan Standar Deviation dengan nilai

291.76640 dan K-Harmonic Means2 dengan nilai Mean 3.2242 dan nilai Standar Deviation sebesar 4.51721 yang ditampilkan pada Tabel 4.14 dibawah ini. 
Tabel 4.14 Deskripsi Statistik K-Harmonic Means

\begin{tabular}{|l|r|r|r|}
\hline \multicolumn{4}{|c|}{ Descriptive Statistics } \\
\hline & \multicolumn{1}{|c|}{ Mean } & Std. Deviation & \multicolumn{1}{|c|}{$\mathrm{N}$} \\
\hline K_Harmonic_Means1 & 211.5100 & 291.76640 & 2 \\
K_Harmonic_Means2 & 3.2242 & 4.51721 & 2 \\
\hline
\end{tabular}

Gambar 4.7 merupakan tampilan Grafik Nilai fungsi dari bobot $x i$, dimana $\mathrm{K}$ Harmonic Means2 memiliki nilai yang tinggi dibandingkan dengan K-Harmonic Means1, yang dapat dilihat pada gambar dibawah ini.

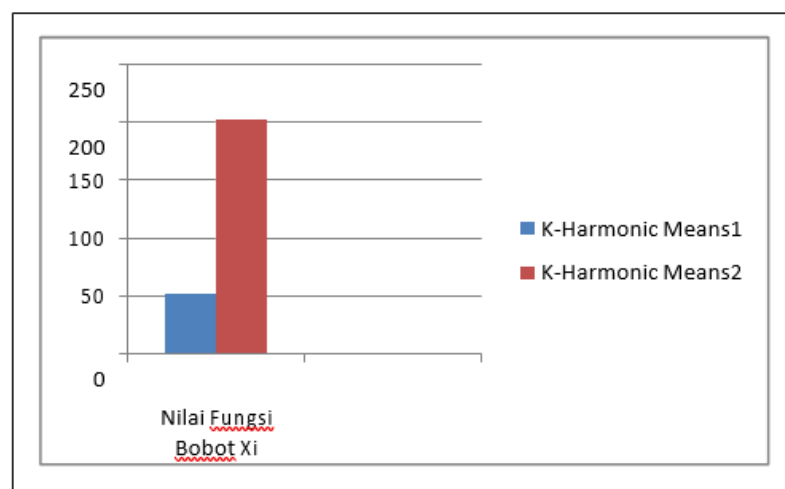

Gambar 4.7 Grafik Nilai Fungsi Bobot Xi

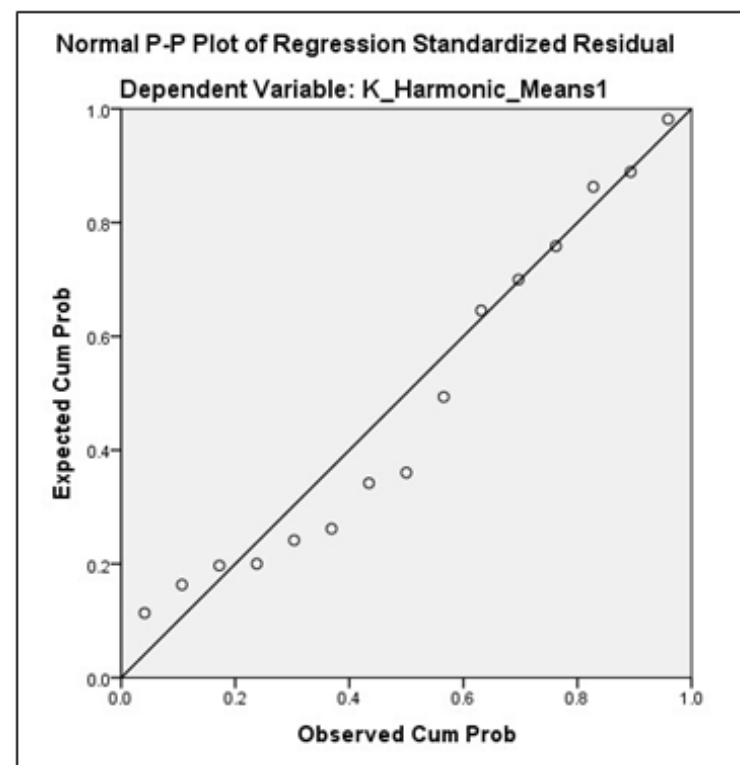

Gambar 4.8 Regression Standardized Residual
Gambar 4.8 merupakan Regression Standardized Residual dari implementasi SPSS Statistic dari variable K-Harmonic Means1 dimana titik- titik pada variable Observed Cum Prob lebih mengakuisisi titik yang lebih banyak di banding titik pada variable Expected Cum Prob.

Peneliti selanjutnya melakukan pengujian dengan mengukur tingkat accuracy dari hasil implementasi IBM SPSS Statistic dengan menggunakan Confucion Matrix dari data hasil prediksi positive yang benar sebesar 52.01, prediksi positive yang salah sebesar 211.51, prediksi negative yang benar sebesar 202.53, dan prediksi negative yang salah 3.22 seperti yang ditampilkan pada Tabel 4.15 dibawah ini:

Tabel 4.15 Nilai-nilai Prediksi

\begin{tabular}{|c|c|c|c|}
\cline { 3 - 4 } \multicolumn{2}{c|}{} & \multicolumn{2}{c|}{ Target } \\
\cline { 3 - 4 } \multicolumn{2}{c|}{ Model } & Positive & Negative \\
\cline { 2 - 4 } & Positive & 202.53 & 3.22 \\
\hline & Negative & 52.01 & 211.51 \\
\hline
\end{tabular}

Tabel nilai hasil prediksi dapat di ketahui dengan jelas nilai dari masing-masing prediksinya yang dapat dilihat pada Tabel 4.16.

Tabel 4.16 Nilai Hasil Prediksi

\begin{tabular}{|c|c|c|c|c|}
\hline \multicolumn{2}{|c|}{ Confucion Matrix } & \multicolumn{2}{|c|}{ Taget } & \multirow{2}{*}{} \\
\cline { 3 - 4 } & Positive & Negative & \\
\hline \multirow{2}{*}{ Model } & Positive & 202.53 & 3.22 & $\begin{array}{c}\text { Positive } \\
\text { Predictive Value } \\
: 98 \%\end{array}$ \\
\cline { 2 - 5 } & Negative & 52.01 & 211.51 & $\begin{array}{c}\text { Negative } \\
\text { Predictive Value } \\
: 77 \%\end{array}$ \\
\hline & Sensivity : & Specificity : & Accuracy $=88 \%$ \\
$98 \%$ & $53 \%$ & & \\
\hline
\end{tabular}


Dari kedua hasil penelitian algoritma KMeans Clustering dengan implementasi RapidMiner dan algoritma K-Harmonic Means dengan implementasi IBM SPSS Statistic, dan hasil keduanya diujikan dengan confution matrix maka didapatilah hasil komparasi pada tiap-tiap algoritma yang ditunjukkan pada Tabel 4.17 dibawah ini :

Tabel 4.17 Hasil Komparasi Akhir Algoritma K-Means dan K-Harmonic Means

\begin{tabular}{|c|c|c|c|c|c|c|c|c|c|c|}
\hline \multirow[t]{2}{*}{ Dataset } & \multicolumn{2}{|c|}{$\begin{array}{l}\text { Positive } \\
\text { Predictive }\end{array}$} & \multicolumn{2}{|c|}{$\begin{array}{c}\text { Negative } \\
\text { Predictive }\end{array}$} & \multicolumn{2}{|c|}{ Sensivity } & \multicolumn{2}{|c|}{ Specificity } & \multicolumn{2}{|c|}{ Accuracy } \\
\hline & KM & KHM & KM & KHM & KM & KHM & KM & KHM & KM & KHM \\
\hline 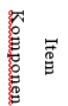 & $73 \%$ & $98 \%$ & $67 \%$ & $77 \%$ & $67 \%$ & $\mathbf{5 3} \%$ & $73 \%$ & $98 \%$ & $70 \%$ & $88 \%$ \\
\hline
\end{tabular}

Dari hasil komparasi akhir algoritma KMeans Clustering dan K-Harmonic Means Clustering yang ditampilkan pada tabel 4.17 diatas, hasil Positive Predictive, Negative Predictive, Specificity, dan Accuracy untuk KHM lebih baik dibanding KM, namun untuk hasil Sensivity KHM kurang baik dibanding KM. Semakin baik hasil akhir accuracy yang diperoleh, maka accuracy yang dimiliki semakin baik (McDuffe, 2010).

\section{KESIMPULAN}

Berdasarkan hasil eksperimen, dapat disimpulkan sebagai berikut :

1. Hasil dari penerapan model algoritma KMeans Clustering dengan implementasi RapidMiner didapatkan jumlah cluster sebanyak 2 buah, yang terdiri dari cluster_0 sebanyak 17 item dan cluster_1 sebanyak 23 item dengan total jumlah data sebanyak 40 item.

2. Hasil dari penerapan model algoritma KHarmonic Means Clustering dengan implementasi IBM SPSS Statistic didapatkan deskripsi statis untuk K-
Harmonic Means1 211.5100 dan KHarmonic Means2 3.2242.

3. Grafik dengan model algoritma K-Means Clustering menunjukkan item replacemen memiliki tingkat tertinggi pada cluster_1 dan cluster_0 pada repair. Sedangkan pada pemodelan algoritma K-Harmonic Means Clustering grafik tertinggi dimiliki oleh $\mathrm{K}$ Harmonic Means2.

4. Hasil pengujian dengan menggunakan Confusion Matrix untuk model algoritma KMeans Clustering didapati prediksi positive $=73 \%$, prediksi negative $=67 \%$, sensitivity $=67 \%$, specificity $=73 \%$, dan accuracy $=$ $70 \%$. Sedangkan untuk model algoritma $\underline{\mathrm{K}}$ Harmonic Means Clustering didapati prediksi positive $=98 \%$, prediksi negative $=77 \%$, sensitivity $=53 \%$, specificity $=$ $98 \%$, dan accuracy $=88 \%$.

\section{REFERENSI}

Agustina, S., Yhudo, D., Santoso, H., Marnasusanto, N., Tirtana, A., \& Khusnu, F., Clustering Kualitas Beras Berdasarkan Ciri Fisik Menggunakan Metode K- Means Algoritma (2014).

Asti, M. M., \& Prasetyawan, Y., Penjadwalan Preventive Maintenance berdasarkan Perspektif, 1 (6) - June, 2013, 1012-1108.

Barlow, R., \& Hunter, L., Optimum Preventive Maintenance Policies. Operations Research, 8 (1) - June, 1960, 2241-1082.

Chen, M., Mizutani, S., \& Nakagawa, T., International Journal of Reliability, Quality and Safety Engineering, Random and age replacement policies. 17 (1) - January, 2010, S0218539310003652

Curcuru, G., Galante, G., \& Lombardo, A., Reliability Engineering and System Safety, A predictive maintenance policy with imperfect monitoring. 95 (9) - April, 2010. 
Endrenyi, J., \& Anders, G. J., IEEE Power and Energy Magazine, Maintainability, maintenance, and reliability for engineers, 4, Informa CRC Press, 2006.

Fei, R., Mobley, R. K., \& Wikoff, D. J., Maintenance

Engineering Handbook., Tissue engineering Part C Methods, 7, The McGraw Hill Companies, 2008, New York - USA.

Gaikindo. (2016). Domestic Auto Production By Category 2015.

Hillier, F. S., \& Editor, S., Handbook of production scheduling, Jefferey W. Hermann, 2006, University of Maryland USA.

Joel Levitt, Complete Guide to Preventive and Predictive Maintenance. Industrail Press Inc, Second Edition, Joel Levitt, 2011, New York.

Kamber, M., \& Han, J., Data Mining: Concepts and TechniquesUniversity of Illinois at Urbana-Champaign, 2nd, Jiawei Han, 2008, University of Illinois at Urbana USA.

Kenne, J. P., \& Boukas, E. K., Mathematical and Computer Modelling, Hierarchical Control of production and maintenance rates in a Multiple- product manufacturing systems, 9 (1) - February, 2003, S08957177.

Kumar, S. A., \& Suresh, N., Production and Operations Management, 2nd, New Age International Publishers, 2008, New Delhi India.

Lin, Z. L., Huang, Y. S., \& Fang, C. C., Reliability Engineering and System Safety, Non-periodic preventive maintenance with reliability thresholds for complex repairable systems, 136 (1) - December, 2015, 0951-8320.
Mishra, R. C., \& Pathak, K., Maintenance Engineering and Management, 2nd, PHI Learning Private Limited, 2012, New Delhi - India.

Mobley, R. K., An introduction to predictive maintenance, 2nd, Butterworth Heinemann, 2002, Amsterdam.

Nowlan, F., Reliability Centered Maintenance, U.S Deartment of Commerce, 1978, San Francisco california.

Nyman, D., \& Levitt, J., Maintenance planning and scheduling coordination, 2nd , Industrial Press, 2001, New York.

Oded Maimon, L. R., Data Mining and Knowledge Discovery Handbook, 2nd , Heinemann, 2010, London.

OICA. (2016). Word Motor Vehicle Production By Country And Type, 27.

Oliver, R., \& Rust, R., Service quality: new directions in theory and practice, First, Sage Publications, 1994, London.

Ong, J. O., Implementasi Algoritma KMeans Clustering untuk Menentukan Strategi Marketing, 1 - April, 2013.

Pham, H., \& Wang, H., European Journal of Operational Research, Imperfect maintenance, 94 (3), - March, 1996, 0377 2217.

Purnama, J., Putra, Y. A., \& Kalamollah, M., Metode Age Replacement Digunakan Untuk Menentukan Interval Waktu Perawatan Mesin Pada Armada BUS, 1, Maret, 2015, 978-602-98569-1-0.

Rasindyo, M. R., Kusmaningrum, \& Helianty, Y., Analisi Kebijakan Perawatan Mesin Cincinnati Dengan Menggunakan Metode RCM Di PT. DIRGANTARA INDONESIA, 3(1), Januari, 2015, ISSN 2238-5081. 
Russell, S. J., \& Norvig, P., Artificial Intelligence: A Modern Approach. Artificial Intelligence, 3tth, Artificial Intelligence, 2010, New Jersey.

Sahin, I., \& Polatoglu, H., Quality, Warranty and Preventive Maintenance. First, Springer Science \& Business Media, 1998, New York.

Saikhu, A., \& Okta, Y., Perbandingan Kinerja Metode K-Harmonic Means dan Particle Swarm Optimization untuk Klasterisasi Data, 7 (2), - Juli, 2002, 1978-0087.

Syahruddin., Analisis Sistem Perawatan Mesin Menggunakan Metode Reliability Centered Maintenance ( RCM ) Sebagai Dasar Kebijakan Perawatan yang Optimal di PLTD “ X .”, 1 (1) - Oktober, 2013, 23386649.

Thearling, K., \& Ph, D., An Introduction to Data Mining, 1 (47) - Februari, 2005. WaiFah Chen, Lian, \& D., Bridge Engineering Handbook 2nd CONSTRUCTION AND MAINTENANCE, 2nd, CRC Press, 2014, London.

Wang, H., European Journal of Operational Research, A survey of maintenance policies of deteriorating systems. 139 (3) November, 2002, S0377-2217.

Wang, Y., Deng, C., Wu, J., Wang, Y., \& Xiong, Y., Engineering Failure Analysis, A corrective maintenance scheme for engineering equipment, 36 (1) - Oktober, 2014, 1108-1016.

Wardhani, A. K., Jurnal Transformatika, KMeans Algorithm Implementation for Patients Disease in Kajen Clinic of Pekalongan, 14 (1) - Juli, 2016, 30-37.

Wicaksana, I. W. S., Belajar Data Mining dengan RapidMiner, First, Remi Sanjaya, 2013, Jakarta - Indonesia.

Yang, F., Sun, T., \& Zhang, C., Expert Systems With Applications, Expert Systems with Applications An efficient hybrid data clustering method based on K- harmonic means and Particle Swarm Optimization, 36 (6) - March, 2009, 9847-9852.

Yoo, J., \& Lee, I. S., Computers \& Industrial Engineering, Parallel machine scheduling with maintenance activities. 101 September, 2016, 1016-1020.

Zhang, B., Hsu, M., \& Dayal, U., Clustering Algorithm K -Harmonic Means -A Data Clustering Algorithm, 1 (26) - June, 1999.

Zhao, X., Al-khalifa, K. N., Magid, A., \& Nakagawa, T., Reliability Engineering and System Safety, Age Replacement Models : A Summary with New Perspectives and Methods. 1 (161) - Januari, 2017. 